\begin{tabular}{|c|}
\hline Journal of Political Science \\
(A Peer-Reviewed, Open Access International Journal) \\
ISSN 2362-1273 (Print); ISSN 2773-8132 (Online) \\
Volume 21, Feburary 2021, pp. 31-38 \\
https//: www.ejournal of pncampus.edu.np/journals/ips/ \\
\hline
\end{tabular}

\title{
Local Governance in Nepal: A Study of Machhapuchhre Rural Municipality, Kaski
}

\author{
Girdhari Dahal, PhD \\ Department of Political Science \\ Prithvi Narayan Campus, Pokhara
}

Corresponding Author: Girdhari Dahal, Email: girdhari.dahal@prnc.tu.edu.np DOI: https://doi.org/10.3126/jps.v21i0.35261

Received 2 December, 2020, Reviewed 15 December 2020, Published 1 February 2021

\begin{abstract}
The election of the local government was held in 2017 after 20 years and paved the way of practicing local governance. This paper aims to study governance practices in Machhapuchhre rural municipality and analyze its key performances. It is based on the sources of primary and secondary data. The municipality has formulated 15 acts, 4 regulations, 27 codes of conducts, 2 directives during these three years of democratic exercise at local level. This municipality also developed various infrastructures including provision of teaching in Magar language as mother tongue in a primary school. Despite these, the municipality is facing shortage of human and financial problems.
\end{abstract}

Keywords: Capacity, local government, promulgation, service delivery

\section{Introduction}

Local government can be defined as the lowest tiers of government which are responsible for managing local affairs by the locally elected people (Asaduzzaman, 2017). In terms of structures, power and functions, local governments vary from country to country such as in India, South Africa and Brazil (Do Vale, 2015). The local government autonomy, its strength and inherent contradictions in achieving the objectives of the local government system happened in Nigeria (Adeyemo, 2005). The local level authority has been in practice in Nepal since the ancient period. The constitution of Nepal 2015 has delegated more power and authority to the local government in comparison to the past.

Local government (LG) is a public institution in a small geographic area as a city, a town, or a county, which are the closest and trustworthy institutions of the local people (Acharya, 2018). In 2015, Nepal promulgated the Constitution of Nepal that envisions the concept of local governance, and three levels of governments: at federal, provincial and local level. 


\section{Local Governance in Nepal}

Nepal has provisioned for a federal democratic republican government that is also called the central government, seven province-level governments and 753 local governments, which have been newly elected and are actively working at present. In the federal system, there are three tiers of government in practice in Nepal.

There are five local government units in in Kaski district. Among them, Machhapuchhre is a rural municipalities, surrounded by Madi Rural Municipality in the East, Annapurna Rural Municipality in the West, Manang District in the North and Pokhara Metropolitan City in the South. Its head quater is located in Lahachock.

During theses periods (2017-2020) the Municipality has succeeded in formulating and implementing 48 laws, rules and regulations. Major development activities have been conducted by local governments, including Machhapuchhre Rural Municipality. They have constructed road networks to connect rural municipality offices to different wards and villages. Similarly, development of drinking water and irrigation systems, reform of agricultural programs, development of education and health infrastructures and services as well as social security, empowerment, preservation of culture and environment and other day to day service deliveries are other significant activities of local governments. Local government is the locally elected government, that provide goods and services to local people effectively.

\section{Objective}

The main objective of this paper is to explore governance practices at local levels, specially in Machhapuchhre Rural Municipality. The paper seeks to identify and critically analyze the evaluation of the key performance of the municipality. It has focused on enhancement of mobilization of local resources by abiding law and perpetual improvement in local bodies.

\section{Methodology}

This study is based on qualitative and quantitative data. Primary data were collected through the interviews, email interviews, and telephone interviews with 10 respondents. Out of them Chairman, Vice Chairman, ward chairmen of different wards and some schools teachers are the main respondents for this study. Out of the nine wards in the rural municipality, 5 ward chairmen were selected through a convenient and purposive sampling method. The interviews were taken at the convenient time of the respondents. The chairman explained the vision, mission, goal and development plans of the rural municipality. The data were collected from January to June 2020. Secondary data were collected from the constitution of Nepal, 2015, local government operation act, 2017, local governance act, 1999, books, journal articles, and reports.

\section{Review of Literature}

The word 'governance' is old as human civilization (Sheng, 2019). It denotes different things in different contexts, but the concept generally relates to group decision making to address 


\section{Local Governance in Nepal}

shared problems (Esty, 2006). Governance is widely understood, when used with regard to government or the public sector, to refer to the institutional underpinnings of public authority and decision making (Harvard, 2012). Good governance, on this view, requires deliberation in a vibrant public sphere as well as good electoral participation and broader patterns of citizen engagement (Farrington, 2011).

Federalism, is a distribution of power which creates more space in strengthening democracy. The Constitution of Nepal 2015 contains a list of 22 concurrent powers for local government, Local Government Operation Act, 2017 outlines the roles and responsibilities of Urban and Rural Municipalities, District. Councils/District Coordination (MOFALD, 2017). The wards are regarded as the very closest unit of the government to the people. They ensure access to basic services people at their doorsteps.

Similarly, development projects and programs, basic and secondary education, basic health service and sanitation, management of local markets, environment conservation and preservation of biodiversity, construction of local, rural and agriculture roads, development of drinking water and irrigation systems fall under the jurisdiction of local governments.

As per Article 217 of the constitution, the judicial committee consists of three-member committee, has the right to settle the disputes through mediation. Local government promotes and strengthens local democracy. It provides an opportunity to local people to participate in the process of planning, decision making and its implication in their everyday life (Shrestha, 1989). It is the basis for the healthy growth of a national level government and serves as a training ground for the future leaders of a country. Shrestha writes local government is an instrument of national integration in the countries with ethnic groups having cultural, linguistic and religious diversities (Shrestha, 1989). This paper takes law making, planning, service delivery and development activites as the independent variables to explain the state of Machhapuchhre rural municipality. These are the main functions of local government.

\section{Concept}

Local government consists of locally elected government and bureaucrats who have the authority to make decisions and execute policy in its territorial area and is responsible for delivering a wide range of services to its people. It is responsible and accountable to its electorate. In the words of Shrestha (1989) local government is responsible for managing multi-dimensional local affairs, including the political role, administrative role, development activities and delivery of services at local level. Thus, local government existed in improving the living standards of local people.

\section{Results and Discussion}

The constitution has devolved legislative, executive and judicial bodies up to the local government, a major shift from 'government' to 'governance' and transformation from hierarchic to more network system (Acharya, 2018). The elected representatives and employees of the local government are committed in improving the quality of life and to provide better public services. The Machhapuchhre Rural Municipality has formed various 


\section{Local Governance in Nepal}

laws to guarantee good governance. The people of the rural area desire for welfare provisions and good management and better delivery of goods and services. In a short time, there have been significant achievements of local governments (Lamsal, Surya P., personal communication, June 1, 2020). Federal government provides financial grants as well as others rights for the development and strengthening of the local government. It shows the vision of periodic election and the grass root democracy will be institutionalized.

\section{Law Making}

According to the provision of the constitution, Machhapuchhre Rural Municipality has formulated more than two dozens of important laws as Acts, rules, operation guidelines, policies and codes of conducts (Gurung, KB, personal communication, January, 2020). According to the constitutional provision, the municipality has formulated the Judicial Committee Act 2018, Disaster Management Act 2018 and Financial Act 2018. Likewise, it has formulated Education Act and Regulation 2018, Health Regulation Act 2018, Public School Distribution Operation 2018, Education Act 2018, and Education Rule 2018, Machhapuchhre Cooperative Act 2019, Natural Resource and Disaster Act 2018, and Local Health Sanitation Act 2019. Similarly, Infrastructure Implication, Home Construction Policy and Code of Conducts have also been promulageted. These policies and laws are facilitating in providing service delivery to the people. According to Surya Lamsal, the municipality has so far promulgated 15 acts, 13 regulations, 4 codes of conduct. The following section shows detailed of laws formulated in different subjects and years.

Table of Laws Made by Machhapuchhre Rural Municipality in Different Years

\begin{tabular}{|l|l|l|}
\hline Description & Years & Number \\
\hline Acts & $2018,2019,2020$ & 15 \\
\hline Regulations & $2017,2018,2019,2020$ & 4 \\
\hline Procedural laws & $2018,2019,2020$ & 27 \\
\hline Directive & 2017 & 2 \\
\hline Total & & 48 \\
\hline
\end{tabular}

Source: Machhapuchhre Rural Municipality Office, 2020

Table 1 shows that the local government has made 15 acts within four years. The local government has made Education Act, Financial Act, Cooperative Act, Disaster Management Act, Health and Sanitation Act. Similarly, the local government has made 4 rules and regulations about education, health, work division and evaluation. 27 procedural laws have made senior citizen indentity cards, child rights, intergrated property tax, meeting management, rural municipality assembly and essential code of conduct directive for their people interest and day to day service delivery essential to the people. The elected government is responsible for the sovereign people of the local level. Now, the local government has not any legal problem for service delivery and development activities at the local level. It is a good opportunity for local leaders for leadership development. It is a great achievement of the local government.

During these three years the elected leaders of the Machhapuchhre Rural Municipality have succeeded in drafting and implementing various laws and conducting development activities. The municipality has constructed the network of roads to connect the 


\section{Local Governance in Nepal}

municipality center to each ward, villages and toles (Dawadi, Krisna Kumari, personal communication, June 1, 2020). Many local people have benefited following the use of improved seeds, modern technology with irrigation facilities. The municipal has declared some areas as agriculture pocket sectors.

The municipality has formulated Education Act and Regulation to guarantee quality education, and has decided to run English medium classes in some schools (Gurung, Bikram, personal communication, April 25, 2020). More importantly, one of the primary schools has used Magar tongue as a medium of instruction to guarantee education in mother tongue for the students. It is a better practice to implement constitutional rights to get education in mother tongue as Machhapuchhre Primary School of Mahara Rivan Village in ward No. 5 decided to provide basic education to their students in Magar Tongue (Adhikari, Jibnath, personal communication, 2 June, 2020). It is really a great achievement of the rural municipality. Rural tourism also promotes through the facilities of hotels and restaurants, fast track management by the LG.

The constitution of Nepal has delegated adequate power and authority to the local government. The 'Local Governance Operation and. Management Act 2017' put forward a strong legal foundation in institutionalizing legislative, executive and quasi-judiciary practice of the newly-formed local government. According to local act, local people are participating in planning, decision making, budgeting and implementation of the plans. But the municipality lack needed human resources and adequate budget to implementation the plans and programs effectively. Likewise, the elected representatives lack capabilities in drafting the laws, In reality, people's participation in drafting the law is absence. There is a culture of hiring a legal expert to draft the laws. These laws are passed without adequate discussion and presence of civil society.

\section{Planning}

The people's participation is the foundation in institutionalizing democracy and leadership development at local level. The devolution of power by the constitution has empowered the local people in the selection of plans and programs according to the guide line provded by the federal government. The community development committees collect the needs from the tole and makes a long list and sets according to the priorities. All the selected plans are discussed in the ward meeting chaired by the Ward Chairman (Dhugana, Harischandra, personal interview, June 1, 2020). After wide consultation and discussion the selected plans and projects are forward to the assembly of Machhapuchhre Rural Municipality. The different sectoral plans are integrated into a single.

\section{Service Delivery and Developement Activities}

Local government exists for local people and tries to solve the problems of the local people. Machhapuchhre Rural Municipality is providing numerous services to the people most of them are related to people's welfare and development activities. In comparsion to past, the local government has improved its capabilities in service delivery. Like in other parts of the country, the community health programmes are playing important role in the community to promote health status of local people. Although there is deficiencies in the existing 


\section{Local Governance in Nepal}

capability of the local health center, the health workers are providing health insurance awareness and medicines. The municipality organized health camps in each ward regularly with the support of the government and non government organizations.

Most of the municipalities of Nepal are giving prime importance to road construction. Accordingly, this municipality is upgrading the existing roads that links Municipality office to all of nine ward offices and ward centers to the communities (Gurung, Birendra, personal communication, June 1, 2020).

The study found that pure drinking water is the second priority of the municipality. The municipality has a plan to provide one tap to each household. Likewise, according to plan people are engaged in constructing and upgrading new irrigation systems. In order to improve quality education at school level, a new management committee has been formed. Agriculture is the main occupation. The municipality has been providing new and advanced technology and improved seeds. This has benefited local people. Each ward office has upgraded and started e-based services delivery. The political change has symbolically brought many positive changes in rural municipality. Sad to say, the elected people's representatives have not been fully successful to fulfil the declaration in their election manifesto.

\section{Conclusion}

Local government is the government at your locality. It exists to provide service delivery along with social and economic development. Under the changed political system, local governments in Nepal are using the devolution of power. Machhapuchhre Rural Municipality is providing service as well as local policy making. Local people are actively participating in their planning, budgeting and monitoring in development activities. Local government has began delivering social service from the ward office. Physical infrastructure development like a connectivity road is being constructed. Local government are decisive stakeholders in reforming the education, health system and drinking water at local level. It faces financial problems for the fulfillment of the people's interest. Similarly, local governments lack good mainpower for improving their service delivery.

Machhapuchhre Rural Municipality has made 15 acts, 4 rules of regulations, 27 procedural laws, 2 directive for its social and physical development. Local government is the foundation of democracy. These law-making processes are improving their capacity development and making elected representatives of the rural municipality responsible. Similarly, it has developed various infrastructures such as road construction, drinking water systems, irrigation system, and social education, use of Magar mother tongue language in one primary school, health sector reform and effective day to day service delivery.

Based on these findings, the study suggests that instead of a conventional local government system, a 'partnership based form' of local governance system would work for the future Nepal in order to ensure good governance and sustainable development. Good governance is important; people can enjoy it through the governance at local level. Local government has many opportunities; it is the base of democracy. Similarly, it is a grassroot to learn and develop leadership capacity. effective and offensive service delivery. Good governance is a relatively new concept on the development activities of the local level. People participation based local governance systems require cooperative effort based on mutual respect. 


\section{Local Governance in Nepal}

\section{References}

Acharya, K. K. (2018). Local governance restructuring in Nepal: From government to governmentality. Dhaulagiri Journal of Sociology and Anthropology, 12, 37-49.

Act and Rule Compile Documents. (2019). Machhapuchhre Rural Municipality Office, Lahachok, Kaski.

Adeyemo, D. O. (2005). Local Government Autonomy in Nigeria: A Historical Perspective. Journal of Social Sciences, 10(2), 77-87. https://doi.org/10.1080/09718923.2005.11892462.

Asaduzzaman, M. (2017). Development Role of Local governance Institutions in Bangladesh: An Empirical Overview, Nepalese Journal of Public Policy and Development Role of the Local Governance Institutions in Bangladesh Empirical Overview. 1.

Bowen, G. A. (2006). Grounded Theory and Sensitizing Concepts. International Journal of Qualitative Methods, 5(3), 12-23. https://doi.org/10.1177/160940690600500304.

Do Vale, H. F. (2015). Comparing and measuring subnational autonomy across three continents. Lex Localis, 13(3), 741-764. https://doi.org/10.4335/13.3.741-764(2015).

Esty, D. C. (2006). Good governance at the supranational scale: Globalizing administrative law. Yale Law Journal, 115(7), 1490-1562. https://doi.org/10.2307/20455663.

Farrington, C. (2011). Putting good governance into practice III: Measuring intrinsic and instrumental empowerment in local government contexts. Progress in Development Studies, 11(2), 151-161. https://doi.org/10.1177/146499341001100205.

Government of Nepal. (2015). Constitution of Nepal, 2015 (2072 BS). http://www.lawcommission.gov.np/en/archives/category/documents/prevailinglaw/constitution/constitution-of-nepal.

Harvard, T. (2012). Good Governance: The Inflation of an Idea. Journal of Food System Research, 19(3), 225-355. https://doi.org/10.5874/jfsr.19.225.

MOFALD. (2017). Local Government Operation Act, 2017, Ministry of Federal Affairs and General Administration, Government of Nepal. 1-86.

National Indicators for Local Authorities and Local Authority Partnerships: Handbook of Definitions.

Nepal Government, Kanun Kitab Bebastha Samittee. (1990). The Constitution Kingdom of Nepal 1990. Kathmandu.

Nepal Government, Kanun Kitab Bebastha Samittee. (2015). The Constitution of Nepal. Kathmandu.

Rijal, Yogendra Raj. (2011). Government Institutions and Local Governance, Kathmandu: Bhrikuti Academic Publication.

Sheng, Y. K. (2009). What is good governance.United Nations Economic and Social Commission for Asia and the Pacific.https://www.unescap.org/resources/what-goodgovernance.

Journal of Political Science, Vol. 21, February 2021 


\section{Local Governance in Nepal}

Shrestha, Tulsi Narayan. (1989). Nepalese Administration a Historical Perspective, Kathmandu: Rhino Publications. 